effective, when present at the time of irradiation. On the contrary, AET failed in exertion of protective action in the concentration so far as examined, irrespective of whether it was added before or after the irradiation.

The discrepancy between our result and others reporting the effectiveness of AET in vivo has remained unsolved. It may be probable that cysteamine and AET do not necessarily play the same part in protection in vivo. In this connexion, the marked difference between cysteamine and AET in their noxious effect on the incorporation into organic acid-soluble phosphate is worthy of note.

This work was supported by the Synthetic Research Fund of the Ministry of Education (Chemical Protection against Radiation).

ICHIJIRO HONJO

YUONG-TCHEL TCHOE

YASUHIKO TAKAMORI

Mitsuhiko Akaboshi

Department of Biology,

Faculty of Science,

Osaka University,

Osaka,

Japan.

${ }^{1}$ Honjo, I., Watanabe, S., and Tehoe, Y.-T., Isotopes and Rad., 2, 225 (1959). ${ }^{2}$ Henke, H., Maass, H., and Sehubert, G., Strahlentherapie, 106, 253 (1958). ${ }^{3}$ Sibatani, A., Exp. Cell Res., 17, 131 (1959).

- Tehoe, Y.-T., Takamori, Y., Akaboshi, M., and Honjo, I., Intern. J. Rad. Biol., 5, 493 (1962).

${ }^{5}$ Khym, J. X., Shapira, R., and Doherty, D. G., J. Amer. Chem. Soc., 79, 5683 (1957).

\section{Changes in the Excretion of Sodium by Saliva after Whole-body Irradiation in Rats}

We have investigated the excretion of sodium in the saliva of irradiated rats by means of the radioisotope of sodium-22. The following method was used. White male rats of the laboratory strain weighing 150-200 g were divided into three groups : the first group containing 10 rats formed controls, the second and third groups consisted of 20 rats each. The animals were fed by a standard diet and accepted water ad libitum.

All the rats were administered intraperitoneally $25 \mu \mathrm{c}$. of sodium-22 in $1 \mathrm{~cm}^{2}$ of physiological solution per $\mathrm{kg}$ of the live-weight. After $24 \mathrm{~h}$, the second and third groups of rats were irradiated with a dose of $1,000 \mathrm{r}$. by an X-ray Macrophos apparatus at $200 \mathrm{kV} ., 15 \mathrm{~m} . \mathrm{amp}$, focus distance of $120 \mathrm{~cm}$. The time exposure amounted to $105 \mathrm{~min}$;

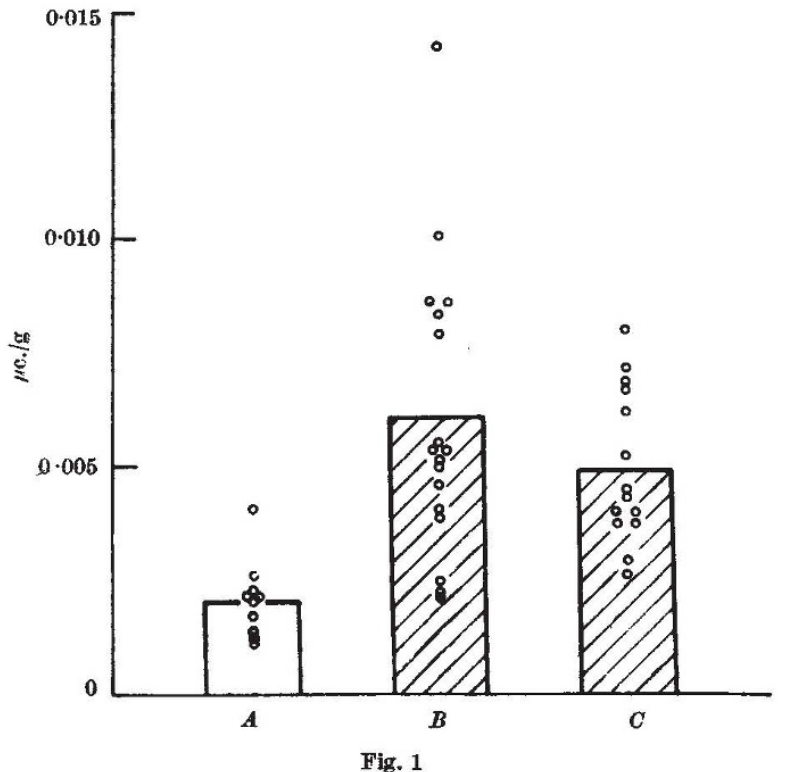

$0.5 \mathrm{~mm}$ aluminium and $0.5 \mathrm{~mm}$ copper were used as filter. The dose was controlled by means of a Mecapion dosemeter. After the exposure 3 animals survived 2 days, and 6 animals 3 days. Ten animals in the last group were used as controls.

Samples of saliva were taken from the first and third groups $96 \mathrm{~h}$ after exposure and from the second group $72 \mathrm{~h}$ after exposure. Just before saliva was taken, the whole-body radioactivity was measured by means of a whole-body counter with 6 Geiger-Müller tubes which was designed in our Institute ${ }^{1}$. Saliva was taken for $20 \mathrm{~min}$ according to Benarde et al. ${ }^{2}$ under thiopental anæsthesia after the administration of 'Pilocarpin'. Thiopental was applied at a dose of $45 \mathrm{mg} / \mathrm{kg}$ intraperitoneally, 'Pilocarpin' at a dose of $10 \mathrm{mg} / \mathrm{kg}$ of the live-weight, subcutaneously. The samples obtained were weighed and using a standard the radioactivity was determined by an end-window tube for measuring $\beta$-radioactivity.

As the rats excrete the administered radiosodium in urine and freces at differing rates, it was necessary to correct the results of radiosodium concentration in saliva accordingly. If the initial activity administered to one rat amounted to $A_{0}(\mu \mathrm{c}$.$) , the activity of the same rat,$ when saliva was taken, measured by the whole-body computer, was $A(\mu \mathrm{c}$.$) , the concentration of radiosodium$ obtained in saliva $\mathrm{c}(\mu \mathrm{c} . / \mathrm{g})$, then the corrected value of concentration corr. $(\mu \mathrm{c} . / \mathrm{g})$ was computed from the following equation :

$$
\text { corr. }=\mathrm{c} \frac{A_{0}}{A}
$$

The results are plotted in Fig. 1.

The corrected concentration of radiosodium in $\mu \mathrm{c} . / \mathrm{g}$ of saliva is plotted on the abscissa. The height of column $A$ represents the average value of the concentration in controls. The individual points describe the individual values of radiosodium concentrations in saliva. Similarly column $B$ represents the average value and individual values of concentration in rats $72 \mathrm{~h}$ after exposure, and column $C$ in rats $96 \mathrm{~h}$ after exposure.

There is a significant increase of radiosodium concentration in saliva of rats exposed to a dose of $1,000 \mathrm{r}$. after 72 and $96 \mathrm{~h}$ as compared with controls. The probability of the insignificance of differences of both experimental groups in comparison with controls is less than 0.5 per cent.

It has been shown ${ }^{8}$ that the 24 -h period between the administration of sodium-22 and the first action in the organism (exposure) is sufficient time to produce equilibrium between the administered radioisotope and the exchangeable sodium in bodies of rats. Therefore the observed relative changes of the radioisotope concentra. tion may be evaluated similarly as changes in the total sodium concentration in saliva. According to the results in the literature, on about the 3rd and 4th day, changes of concentration of sodium in blood ${ }^{4,5}$ are not so great as to cause the changes in saliva which we observed. It may lead to the conclusion that the values obtained are caused directly by a disturbed mechanism of saliva excretion.

We might find the explanation in a disturbance of the active sodium transport in the cells of chicks in the colum. nar epithelium of ducts.

\section{J. ONDRÁČKova \\ M. RAKOVIð \\ V. Gregora}

Institute of Biophysics,

Medical Faculty, Charles University, Prague.

Boucek, J., Acta Universitatis Carolinae Medica, Suppl, 33, 10 (1960).

${ }^{2}$ Benarde, M. A., Fabian, F. W., Rosea, S., Hoppert, C. A., and Hunt, H. R., J. Dent. Re8., 2, 35 (1956).

' Woodward, K. T., Richmond, C. R., and Langham, w., Proc. Health Phys. Soc., 79 (1956).

Baker, D. G., and Sellers, E. A., Canad. J. Biochem. and Physiol., 34, 835
(1956). 'France, O., U.S. Atomic Eneroy Comm. Rep. NOCH 3889 (1946). 